\title{
Effect of Newly Synthesized Compounds 44Bu and 444 on QRS-Complex Width and Fast Sodium Current: Differences between Isomers
}

\author{
Anna Kilianová ${ }^{1}$, Markéta Bébarová1, Klára Beránková2, Radka Opatřilová ${ }^{3}$, \\ Michal Pásek ${ }^{1,4}$, Ladislava Bartošová ${ }^{2}$ \\ ${ }^{1}$ Department of Physiology, Faculty of Medicine, Masaryk University, Brno, Czech Republic \\ ${ }^{2}$ Department of Human Pharmacology and Toxicology, ${ }^{3}$ Department of Chemical Drugs, Faculty of Pharmacy, \\ University of Veterinary and Pharmaceutical Sciences, Brno, Czech Republic \\ ${ }^{4}$ Institute of Thermomechanics, Czech Academy of Sciences - branch Brno, Czech Republic
}

Received: May 11, 2009

Accepted: September 8, 2009

\begin{abstract}
Two newly synthesized short-acting agents $44 \mathrm{Bu}$ and 444 were observed to suppress the aconitine-induced arrhythmias and block the fast sodium current $I_{N a}$ in the rat heart. No data about their effect on the electrocardiographic parameters are available. In this study, we explored the effect of both racemates and particular isomers of $44 \mathrm{Bu}$ and 444 on the QRS-complex width in vivo in rats and on $I_{N a}$ in isolated rat ventricular myocytes. All variants of $44 \mathrm{Bu}$ and $444(1.5 \mathrm{mg} / \mathrm{kg})$ caused a significant QRS-widening reaching the peak effect at the $1^{\text {st }}$ or $2^{\text {nd }}$ min after their intravenous administration. 44Bu racemate widened the QRS-complex from $16.8 \pm 0.4$ to $26.3 \pm 0.5 \mathrm{~ms}$ (by $57 \%$ ), significantly more than R- (33\%-widening) and S-isomer (36\%-widening). 444 racemate widened the QRS-complex from $20.8 \pm 1.0$ to $34.1 \pm 0.9 \mathrm{~ms}$ (by $64 \%$ ), which was comparable to S-isomer (63\%-widening), however, substantially more than R-isomer (40\%-widening). Regarding the effect on $I_{N a}, 44 \mathrm{Bu}$ caused a significantly deeper $I_{N a}$ block compared to 444 when applied at the same concentration of $3 \mu \mathrm{mol} / 1(\sim 0.1 \mathrm{mg} / \mathrm{kg})$. $44 \mathrm{Bu}$ racemate and R-isomer blocked $I_{N a}$ similarly $(91.7 \pm 0.8$ and $91.8 \pm 1.6 \%$-block, respectively) and significantly more than S-isomer $\left(82.4 \pm 2.3 \%\right.$-block). $444 \mathrm{R}$-isomer blocked $I_{\mathrm{Na}}$ less than racemate and S-isomer (by $31.7 \pm 3.9 \%$ vs. $48.3 \pm 4.7$ and $50.2 \pm 4.1 \%$, respectively). We conclude that both racemates and particular isomers of $44 \mathrm{Bu}$ and 444 induce a QRS-widening and block $I_{N a}$ in the rat heart, however, their effects notably differed. The relative widening of the QRS-complex after application of $44 \mathrm{Bu}$ did not conform to the level of $I_{N a}$-block observed in isolated cardiomyocytes which stresses the importance of in vivo experiments in the pre-clinical testing of new drugs.
\end{abstract}

444; 44Bu; isomer; QRS-complex; sodium current; rat

Despite progressive development and successful use of invasive techniques, the pharmacological treatment is still considered to be the preferred method in many patients suffering from arrhythmias (e.g. Callans 2008) or, in some cases, a combined treatment is desirable (e.g. Singh and Murawski 2007). Unfortunately, beside the beneficial effects, a risk of cardiac adverse effects including life-threatening arrhythmias is related to the use of a majority of the available antiarrhythmic drugs. Therefore, a development of novel agents with antiarrhythmic potency is needed (Roden and Anders on 2006). In the case of acute intravenous treatment, agents with a short period of action are beneficial because they allow to precisely adjust the effective concentration and to readily interrupt the administration if adverse effects appear (e.g. Barbier et al. 1995; Yoshida et al. 2008).

Several new short-acting agents with a prominent antiarrhythmic effect have been synthesized at the Faculty of Pharmacy, University of Veterinary and Pharmaceutical Sciences, Brno, Czech Republic. The compounds with draft names 44Bu and 444, which were tested in this study, are derivates of aryl-carbonyl-oxy-amino-propanols varying in the substituent in the aliphatic chain; 44Bu contains $n$-butyl whereas 444 terc-butyl (Fig. 1; Mokrý et al. 2003). 44Bu was reported to suppress the aconitine-induced 
<smiles>CCCCOC(=O)Nc1ccc(C(=O)OCC(O)C[NH+](Cl)Cl)cc1</smiles>

$44 \mathrm{Bu}$

4 - Butoxycarbonylamino-benzoic acid 3- butylamino-2-hydroxy-propyl ester<smiles>[CH2-][NH+](CC(O)COC(=O)c1ccc(NC(=O)OCCCC)cc1)C(C)(C)C</smiles>

444

4-Butoxycarbonylamino-benzoic acid 3- tert-butylamino-2-hydroxy-propyl ester

Fig. 1. Chemical structure of 44Bu and 444. These compounds are functional analogues of aryloxyaminopropanols modified by the $n$-butyl and terc-butyl in the case of $44 \mathrm{Bu}$ and 444 , respectively.

arrhythmias more efficiently than lidocaine, a class-Ib antiarrhythmic drug (Bartosova et al. 2007). The antiarrhythmic effect of $44 \mathrm{Bu}$ persisted for about $15 \mathrm{~min}$. In recent experiments, 444 has been observed to suppress the aconitine-induced arrhythmias similarly to $44 \mathrm{Bu}$, however, its effect lasted a little longer (unpublished data). Unfortunately, no data related to changes in basic electrocardiographic (ECG) indicators in presence of $44 \mathrm{Bu}$ and 444 are available. Both these agents were documented to considerably block the fast sodium current $I_{N a}$ (Bartosova et al. 2006) which might, at least partly, explain their antiarrhythmic potency.

The currently used drugs are usually available as the racemic mixture (or racemate), i.e. as the equimolar mixture of R- and S-isomer. The above mentioned effects of $44 \mathrm{Bu}$ and 444 on the cardiac electrophysiology were also studied only in presence of their racemates. However, the particular isomers of an optically active compound are often characterized by notably different pharmacokinetic and pharmacodynamic properties (Kulig et al. 2004). Nowadays, a tendency to develop and test new drugs in the form of pure isomers is obvious (e.g. Agrawal et al. 2007). In the case of 44Bu, the S-isomer has been recently observed to suppress the aconitine-induced arrhythmias more efficiently compared to the $\mathrm{R}$-isomer whereas the racemate exerted the best effect in suppressing ventricular fibrillation (Bartosova et al. 2008). As mentioned above, the antiarrhythmic effect of 44Bu and 444 might result from their potency to block $I_{N a}$. Therefore, we decided to explore the level of $I_{N a}$-block under the effect of the racemates and also the particular R-and S-isomers of 44Bu and 444 at the same concentration of $3 \mu \mathrm{mol} / 1$ (for details see 2.1.). We also analyzed the QRS-complex width, a measure of the excitation velocity through the cardiac tissue which should correlate with $I_{\mathrm{Na}}$-block, in absence and presence of all the $44 \mathrm{Bu}$ and 444 variants at a dose of $1.5 \mathrm{mg} / \mathrm{kg}$.

\section{Materials and Methods}

Tested substances

The chemical structure of $44 \mathrm{Bu}$ and 444 was verified by the elementary analysis, IR, ${ }^{1} \mathrm{H}-\mathrm{NMR}$ and ${ }^{13} \mathrm{C}-\mathrm{NMR}$ spectroscopy (Mokrý et al. 2001), purity was verified chromatographically (Mokrý et al. 2003), and elementary physical characteristics were determined (Opatrilova et al. 2005).

The tested substances were dissolved in sterile isotonic $0.9 \% \mathrm{NaCl}$ solution for infusion in in vivo experiments. In the case of in vitro measurements of their effect on $I_{N a}, 44 \mathrm{Bu}$ and 444 were prepared as $1 \mathrm{mM}$ stock solution in deionized water and diluted to the final concentration of $3 \mu \mathrm{mol} / 1$ before each experiment. The concentration of $3 \mu \mathrm{mol} / \mathrm{l}$ corresponds to $\sim 0.1 \mathrm{mg} / \mathrm{kg}$, thus, it is $15 \times$ lower than the concentration used in in vivo experiments. It was selected with the purpose to reveal prospective differences among the level of $I_{N a}$-block in presence of all the optical variants of $44 \mathrm{Bu}$ and 444 because their racemates at the concentration of $10 \mu \mathrm{mol} / 1$ were previously shown to block $I_{N a}$ completely (Bartosova et al. 2006). 
ECG monitoring and evaluation of changes in QRS-complex width

Experiments were performed in vivo on 43 male Wistar laboratory rats $(290 \pm 25 \mathrm{~g})$. The animals came from a conventional breeding colony (Faculty of Medicine, Masaryk University, Brno, Czech Republic). They were housed in agreement with the conditions as per Regulation No. 311/1997 Coll. (temperature - $20-24{ }^{\circ} \mathrm{C}$, humidity 40-60\%, 12:12 L:D cycles with lighting maximum up to 200 lux). The animals were fed a standard diet (Diet for small laboratory animals $\mathrm{M}_{1}$ ) and given water ad libitum. Experimental protocol was approved and monitored by the local University Ethics Committee of the University of Veterinary and Pharmaceutical Sciences in Brno. The animals were anaesthetized by intramuscular administration of a mixture of $1 \%$ ketamine (Narkamon ${ }^{\circledR}$ inj. Spofa, Czech Republic) and 2\% xylazine (Rometar ${ }^{\circledR}$ inj. Spofa, Czech Republic) at a dose of $0.5 \mathrm{ml} / 100 \mathrm{~g}$.

ECG was monitored continuously on a Seiva Praktik ECG machine (Seiva Praktik Veterinary, Czech Republic). The tested substances were administered intravenously into the exposed vena jugularis at a dose of $1.5 \mathrm{mg} / \mathrm{kg}$ (corresponding to $3.72 \mu \mathrm{mol} / \mathrm{kg}$ in the case of both $44 \mathrm{Bu}$ and 444 ).

The ECG records (ECG Seiva Praktik Veterinary) were made at predetermined time intervals (after induction of anaesthesia - the initial value, at the time of administration of the tested substance, at 0.5 and $1 \mathrm{~min}$, at every $1 \mathrm{~min}$ until the $6^{\text {th }}$ min and, subsequently, at every $2^{\text {nd }} \min$ until the $20^{\text {th }} \mathrm{min}$ ). The most significant changes in ECG indicators were observed during the first $5 \mathrm{~min}$. Thus, only this time interval was used for the evaluation. Measurement of the QRS-complex width was done using the ECG-SEIVA Praktik software and the automatic measurement was verified manually if necessary.

Measurement and evaluation of changes in fast sodium current

Ventricular myocytes were isolated from right ventricular free walls of adult male Wistar rats $(250 \pm 50 \mathrm{~g})$ anaesthetised by intramuscular administration of a mixture of $1 \%$ ketamine (Narkamon ${ }^{\circledR}$ inj., Spofa) and $2 \%$ xylazine (Rometar ${ }^{\circledR}$ inj., Spofa) at a dose of $0.8 \mathrm{ml} / 100 \mathrm{~g}$. The experiments were carried out with respect to recommendations of the European Community Guide for the Care and Use of Laboratory Animals. The experimental protocol was approved by the Local Committee for Animal Treatment at Masaryk University, Faculty of Medicine (permission No. 12175/2001-1020(A)).

The dissociation procedure has been previously described in detail (Bébarová et al. 2005). In brief, the heart was retrogradely perfused via aorta with $0.9 \mathrm{mM} \mathrm{CaCl}_{2}$ Tyrode solution and then with nominally Ca-free Tyrode solution. During the first digestion step, the perfusion continued with nominally Ca-free Tyrode solution containing collagenase (type S, Yakult Pharmaceuticals; $0.2 \mathrm{mg} / \mathrm{ml}$ ), protease (type XIV, Sigma-Aldrich; 0.053 $\mathrm{mg} / \mathrm{ml}$ ), albumin (bovine, fraction V, Sigma-Aldrich; $2 \mathrm{mg} / \mathrm{ml}$ ), and EGTA (Sigma-Aldrich; $34 \mathrm{mM}$ ). In the second digestion step, protease and albumin in the enzyme solution were omitted. The enzyme solution was then washed out in two steps by perfusion with low calcium Tyrode solutions $\left(0.09\right.$ and $\left.0.18 \mathrm{mM} \mathrm{CaCl}_{2}\right)$. All solutions were oxygenated with $100 \% \mathrm{O}_{2}$ at $37^{\circ} \mathrm{C}$.

Composition of the Tyrode solution used (mM): $\mathrm{NaCl} 135, \mathrm{KCl} 5.4, \mathrm{CaCl}_{2} 0.9, \mathrm{MgCl}_{2} 0.9$, HEPES 10, $\mathrm{NaH}_{2} \mathrm{PO}_{4}$ 0.33 , glucose $10(\mathrm{pH}$ adjusted to 7.4 with $\mathrm{NaOH}) . \mathrm{CaCl}_{2}(0.9 \mathrm{mM})$ and the calcium channel blocker $\mathrm{CoCl}_{2}(2$ $\mathrm{mM}$; Sigma-Aldrich; prepared as $1 \mathrm{M}$ stock solution in deionized water) were administered in the course of the experiments. The patch electrode filling solution contained (mM): L-aspartic acid 130, $\mathrm{KCl} 25, \mathrm{MgCl}_{2} 1, \mathrm{~K}_{2} \mathrm{ATP}$ 5, EGTA 1, HEPES 5, GTP 0.1, $\mathrm{Na}_{2}$-phosphocreatine 3 (pH 7.25 adjusted with $\mathrm{KOH}$ ).

Single rod-shaped cells with well visible striations were used for $I_{N a}$-measurements applying the whole-cell patch-clamp technique at room temperature $\left(22 \pm 2{ }^{\circ} \mathrm{C}\right)$. The patch pipettes were pulled from borosilicate glass capillary tubes and heat polished on a programmable horizontal puller (Zeitz-Instrumente). The resistance of the filled glass electrodes was below $1.5 \mathrm{M} \Omega$ to keep the access resistance as low as possible. For generation of experimental protocols and data acquisition, the Axopatch 200B equipment and pCLAMP 9.2 software (Axon Instruments, Inc.) were used. The series resistance was compensated up to $80 \%$. The measured current was filtrated with a four-pole Bessel filter at $5 \mathrm{kHz}$, digitally sampled at $20 \mathrm{kHz}$ and stored on the hard disc. Experimental protocol and evaluation of the data are described in Results. The stimulation frequency of $0.2 \mathrm{~Hz}$ was used to avoid an accumulation of $I_{N a}$-block. The tested substances were applied into the close vicinity of the measured cell through a rapid perfusion system.

Statistical analysis

The results are presented as means \pm SEM from $n$ animals/cells. The one-way ANOVA with Bonferroni post test (used to assess the significance of differences between the tested substances both in the case of changes in the QRS-complex width and in $I_{N a}$-block) was performed using GraphPad Prism, version 4.0 (GraphPad Software, Inc.); $P<0.05$ was considered significant.

\section{Results}

Changes in QRS-complex width after administration of 44Bu and 444

Table 1 summarizes averaged values of the QRS-complex width before and during the first $5 \mathrm{~min}$ after administration of the tested substances at a dose of $1.5 \mathrm{mg} / \mathrm{kg}$. All the substances caused a significant QRS-widening which usually culminated 1 to 2 min after their administration. In the case of 444 variants, the QRS-widening started $30 \mathrm{~s}$ after their 
Table 1. Changes in QRS-complex width after administration of 44Bu and 444.

\begin{tabular}{|l|l|l|l|l|l|l|}
\hline & \multicolumn{3}{|c|}{$44 \mathrm{Bu}$} & \multicolumn{3}{c|}{444} \\
\hline & Racemate & \multicolumn{1}{|c|}{ R-isomer } & \multicolumn{1}{|c|}{ S-isomer } & Racemate & R-isomer & S-isomer \\
\hline IV & $16.8 \pm 0.4$ & $16.7 \pm 0.5$ & $16.0 \pm 0.8$ & $20.8 \pm 1.0$ & $21.4 \pm 0.9$ & $20.8 \pm 1.3$ \\
\hline 0 & $17.7 \pm 0.5$ & $17.4 \pm 0.4$ & $16.5 \pm 0.9$ & $21.2 \pm 1.3$ & $24.1 \pm 0.6$ & $23.4 \pm 1.7$ \\
\hline 0.5 & $22.7 \pm 0.6 * * *$ & $20.2 \pm 0.7$ & $20.2 \pm 0.9 *$ & $27.5 \pm 0.4 *$ & $26.7 \pm 0.5 *$ & $28.8 \pm 0.5 * *$ \\
\hline 1 & $26.3 \pm 0.5 * * *$ & $21.8 \pm 0.9 * *$ & $20.9 \pm 1.1 * *$ & $34.1 \pm 0.9 * * *$ & $29.8 \pm 0.8 * * *$ & $33.8 \pm 1.0 * * *$ \\
\hline 2 & $26.3 \pm 0.6 * * *$ & $22.2 \pm 1.1 * * *$ & $21.7 \pm 0.9 * *$ & $33.5 \pm 1.6 * * *$ & $30.0 \pm 1.3 * * *$ & $33.8 \pm 1.3 * * *$ \\
\hline 3 & $25.1 \pm 0.6 * * *$ & $21.8 \pm 1.0 * *$ & $20.7 \pm 1.0 *$ & $31.5 \pm 1.5 * * *$ & $31.7 \pm 1.2 * * *$ & $33.0 \pm 1.4 * * *$ \\
\hline 4 & $24.0 \pm 0.5 * * *$ & $21.8 \pm 1.0 * *$ & $20.1 \pm 0.9$ & $30.8 \pm 1.4 * * *$ & $29.3 \pm 1.5 * * *$ & $32.0 \pm 1.6 * * *$ \\
\hline 5 & $23.2 \pm 0.5 * * *$ & $21.1 \pm 0.7 * *$ & $19.9 \pm 0.8$ & $29.4 \pm 2.0 * *$ & $28.5 \pm 1.1 * * *$ & $30.4 \pm 1.5 * * *$ \\
\hline
\end{tabular}

The absolute value of the QRS-complex width [ms] stated as mean \pm SEM; IV - the initial value; the following records were made at the time point when the tested substance was administrated ( 0 min) and $0.5,1,2,3,4$ and 5 min after its administration; $*_{-} P<0.05, *^{*}-P<0.01, *_{*}^{*}-P<0.001-$ statistical significance of the increase in the QRS-complex width vs. the initial value in the particular variants of $44 \mathrm{Bu}$ and 444 evaluated by the one-way ANOVA with Bonferroni post test.

administration and was highly significant. On the contrary, only the 44Bu racemate exerted highly significant effect which started $30 \mathrm{~s}$ after its administration. In the case of the Rand, especially, of S-isomer of $44 \mathrm{Bu}$, the QRS-widening was considerably smaller and transient compared to the $44 \mathrm{Bu}$ racemate and to all the 444 variants.

For better comparison, we decided to also count the relative percentage changes of the QRScomplex width $(100 \% \sim$ the initial value before administration of the tested substance). Figure 2 clearly shows a significantly higher potency of the 44Bu racemate to cause a QRS-widening in comparison with both its pure isomers (Fig. 2A). In the case of 444, a smaller QRS-widening after administration of the R-isomer compared to its racemate and S-isomer was observed (Fig. 2B). Regarding differences between 44Bu and 444, their peak effect (observed in presence of the racemates of 44Bu and 444, and under the effect of the S-isomer of 444) resulting in an increase of the initial QRS-complex width to about $160 \%$ did not significantly differ. Similarly, the effect of the less effective variants, namely the both particular isomers of $44 \mathrm{Bu}$ and the R-isomer of 444, caused a comparable QRS-widening to values between 132 and $142 \%$.

A

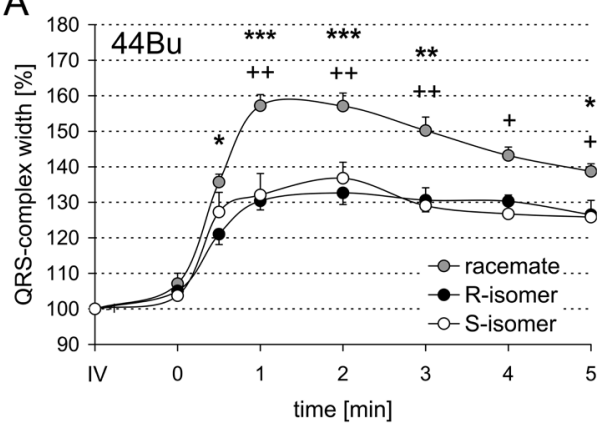

B

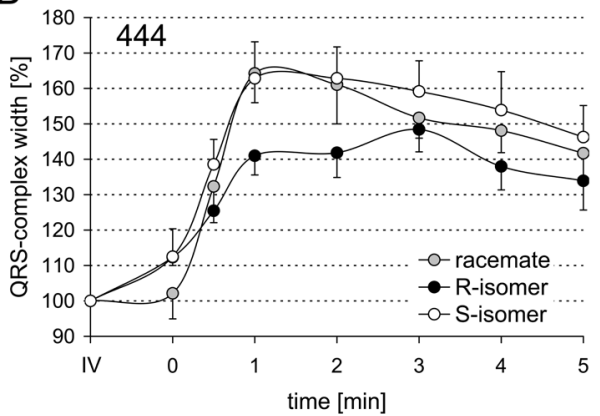

Fig. 2. Percentage changes in the QRS-complex width under the effect of racemate, and R- and S-isomers of $44 \mathrm{Bu}$ $(\mathrm{A}, n=8)$ and $444(\mathrm{~B}, n=5)$.

$100 \% \sim$ the initial value (IV) before administration of the tested substance. All the tested substances increased the QRS-complex width. The effect of 44Bu racemate was significantly higher compared to its R- and S-isomer; *,** and *** - significance at $P<0.05,0.01$ and 0.001 , respectively, for differences between the racemate vs. R-isomer; ${ }^{+}$and ${ }^{+}$- significance at $P<0.05$ and 0.01 , respectively, for differences between the racemate vs. S-isomer. In the case of 444, the R-isomer caused a lower increase in comparison with the racemate and S-isomer which did not differ in their effect; changes were not significant, very likely due to the lower number of animals included in the statistics. 
Effect of $44 \mathrm{Bu}$ and 444 on $\mathrm{I}_{\mathrm{Na}}$

To measure $I_{N a}, 25-\mathrm{ms}$ rectangular pulses from the holding potential of $-75 \mathrm{mV}$ to $-40 \mathrm{mV}$ were applied at the stimulation frequency of $0.2 \mathrm{~Hz}$. The level of $I_{\mathrm{Na}}$-block was evaluated from changes in $I_{N a}$-amplitude after administration of the agents; the changes were corrected for the spontaneous run down of the current. All variants of $44 \mathrm{Bu}$ and 444 caused a reversible block of $I_{N a}$ (illustrated for $44 \mathrm{Bu}$ racemate in Fig. $3 \mathrm{~A}$ and B). In the case of $44 \mathrm{Bu}$ (Fig. 3C, left panel), we observed an almost complete block of $I_{N a}$ after application of the racemate and R-isomer $(91.7$ $\pm 0.8 \%$ and $91.8 \pm 1.6 \%$, respectively; $P>0.05)$ whereas the S-isomer exerted a significantly lower effect $(82.4 \pm 2.3 \% ; P<0.01$ compared to both the racemate and R-isomer). In the case of 444 (Fig. 3C, right panel), the racemate and S-isomer blocked $I_{N a}$ comparably $(48.3 \pm 4.7 \%$ and $50.2 \pm 4.1 \%$, respectively; $P>0.05$ ) but the blocking potency of R-isomer was substantially less $(31.7 \pm 3.9 \% ; P<0.05$ and 0.01 compared to the racemate and S-isomer, respectively). Confronting the effect of various variants of both tested substances, $44 \mathrm{Bu}$ caused significantly deeper $I_{N a}$-block in comparison with $444(P<0.001)$.

A

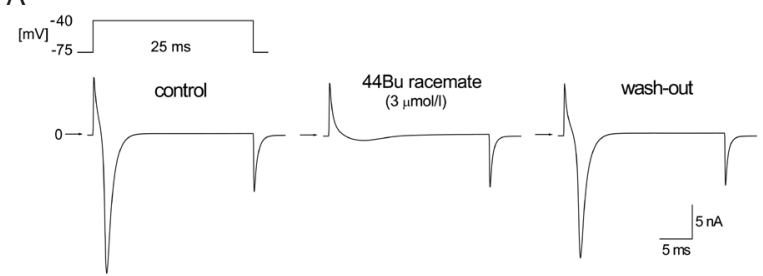

C

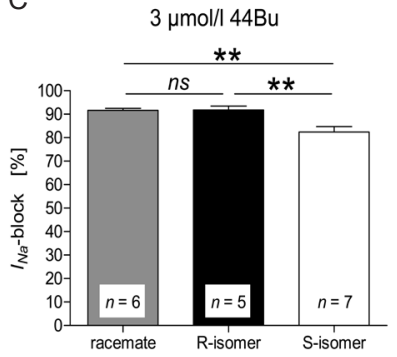

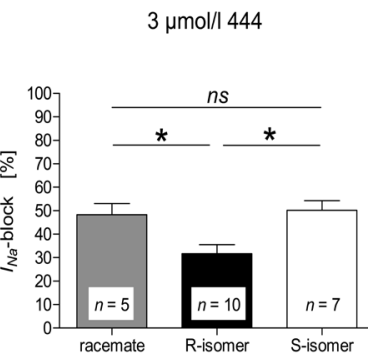

B

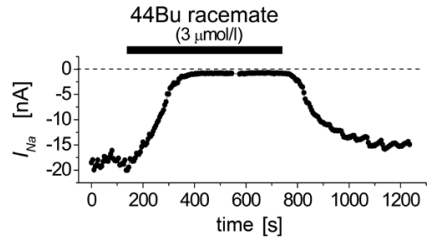

Fig. 3. Effect of racemate and R- and S-isomers of $44 \mathrm{Bu}$ and 444 on the fast sodium current $I_{\mathrm{Na}}$.

A: An example of the original record of $I_{\mathrm{Na}}$ in control conditions, under the effect of $44 \mathrm{Bu}$ racemate at the concentration of $3 \mu \mathrm{mol} / 1$ and after the subsequent wash-out. The experimental protocol was composed of a set of 25 -ms rectangular pulses from the holding potential of $-75 \mathrm{mV}$ to $-40 \mathrm{mV}$ applied at the stimulation frequency of $0.2 \mathrm{~Hz}$. B: Changes in $I_{N a}$-amplitude evaluated during the experiment with $3 \mu \mathrm{mol} / 144 \mathrm{Bu}$ racemate which caused a reversible block of $I_{\mathrm{Na}}$. C: Averaged block of $I_{\mathrm{Na}}$ in presence of all the tested substances at the same concentration of $3 \mu \mathrm{mol} / \mathrm{l} ; n-$ number of experiments, $n s$ - non-significant $(P>0.05),{ }^{*}$ and $* *-P<0.05$ and 0.01 , respectively.

\section{Discussion}

In this study, we have documented that two newly synthesized short-acting agents with draft names $44 \mathrm{Bu}$ and 444 cause a significant widening of the QRS-complex and, in agreement, block $I_{\mathrm{Na}}$ in the rat heart. Substantial differences in the effects of racemates and particular isomers of these agents were observed.

The averaged initial values of the QRS-complex width diverged in the experiments with $44 \mathrm{Bu}$ and 444 (Table 1). However, these differences were not significant and all the values varied within the usually reported range of the QRS-complex width in the rat in vivo (e.g. $14.3 \mathrm{~ms}$ - Akita et al. 1998; $15.1 \mathrm{~ms}$ - Králová et al. 2008; $18.6 \mathrm{~ms}$ - Brisinda et al. 2006; $22.8 \mathrm{~ms}$ - Maatz et al. 2009; about $27 \mathrm{~ms}$ - Saitoh et al. 2002). The diversity of the values is probably related to the fact that effects of $44 \mathrm{Bu}$ and 444 on the QRS-complex width were recorded within two independent sets of experiments. 
The QRS-widening notably differed in the 44Bu and 444 variants. In the case of $44 \mathrm{Bu}$, the effect of the particular isomers seems to potentiate when present together in the racemic mixture (Fig. 2A). In agreement, a study dealing with the antiarrhythmic effect of 44Bu variants has recently showed that the racemate was more effective in suppression of the ventricular fibrillation compared to both its particular isomers (Bartos ova et al. 2008). As for 444, a comparable potency of the S-isomer and racemate to widen the QRS-complex was substantially higher than those of the R-isomer (Fig. 2B). It might imply that the $\mathrm{S}$-isomer is mainly responsible for the pharmacological effect of 444 on the rate of cardiac conduction and, thus, also for its antiarrhythmic effect. Unfortunately, the antiarrhythmic effect of 444 variants has not been studied yet. In the past, other pure isomers were documented to exert the majority of the pharmacological effects of an optically active compound. In some cases, the pure isomer was even shown to provide an advantage in the clinical use of a compound administered in the form of racemate so far (e.g. Valenzuela et al. 1995; Stoschitzky et al. 2001; Magyar et al. 2003; Eap et al. 2007; Wang et al. 2008). Thus, it might be beneficial to produce and test the pure S-isomer of 444 if this compound was considered to be used in the clinical practise in the future.

$I_{N a}$ plays a central role in the cardiac excitability and conduction (for review, see e.g. Remme et al. 2008). Thus, changes in the QRS-complex width, which corresponds to the ventricular depolarization, are considered to be a good indicator of the action of $I_{N a}$-channel blockers (Ranger et al. 1991; Sakai et al. 1995; Shinozaki et al. 1997). In agreement, the QRS-widening recorded in vivo in our study corresponded well to the level of $I_{N a}$-block measured in vitro in isolated ventricular myocytes in the case of 444 (Fig. 2B, and Fig. 3C, right panel). Surprisingly, in the case of 44Bu, changes in these two indicators notably differed (Fig. 2A, and Fig. 3C, left panel). Even complete absence of changes in the QRS-complex width under the effect of a drug blocking $I_{N a}$ has been documented, for example under the effect of mexiletine (Shimizu et al. 2000) and cyclo(Trp-Pro) isomers (Jamie et al. 2002). These differences between results of in vivo and in vitro experiments may be caused, among others (e.g. temperature), by the comprehensive character of the drug effect on a living organism which is primarily influenced by the pharmacodynamic and pharmacokinetic properties of the drug. In the case of $44 \mathrm{Bu}$ and 444 , a variable accessibility of the ester binding in their particular isomers caused by the distinct three-dimensional structure, and, thus, differences in their degradation by esterases might play a role similarly to esmolol, an ultrashortacting blocker of the $\beta$-adrenergic receptors (Quon et al. 1988). The R-isomer of 444 has been recently documented to be degraded by esterases faster in comparison with its $\mathrm{S}$-isomer and racemate (unpublished data) which might explain its weaker effect on the QRS-complex width (Fig. 2B). No parallel data are available in the case of 44Bu. The above discussed facts support the necessity of in vivo experiments within pre-clinical testing of new compounds.

In our previous study (Bartosova et al. 2006), we showed that $10 \mu \mathrm{mol} / \mathrm{l}$ racemates of $44 \mathrm{Bu}$ and 444 induced a complete $I_{\mathrm{Na}}$-block. In the current study, a reversible block of $I_{\mathrm{Na}}$ under the effect of both substances, both in the form of racemates and pure isomers, was documented at the concentration of $3 \mu \mathrm{mol} / \mathrm{l}$ (Fig. 3). These results provide a clear evidence that $44 \mathrm{Bu}$ and 444 are efficient blockers of $I_{N a}$ with the blocking potency comparable to class-I antiarrhythmic drugs (e.g. propafenone - Šimurdová et al. 1997; flecainide -Liu et al. 2002; lidocaine - Xiao et al. 2004; ajmaline - Bébarová et al. 2005). As known, the block of $I_{N a}$ results in a slower rate of conduction, increased threshold for excitation and prolongation of the effective refractory period. These changes may lead to suppression of arrhythmias as reviewed by e.g. Carmeliet and Mubagwa (1998). Therefore, the potency of $44 \mathrm{Bu}$ and 444 to block $I_{N a}$ very likely plays a role in their antiarrhythmic effects which were observed formerly (44Bu - Bartosova et al. 2007; 444 - unpublished data). 
However, further experiments focused on the exploration of other electrophysiological effects of 44Bu and 444 are needed to complete their profiles.

We conclude that the newly synthesized ultra-short acting compounds $44 \mathrm{Bu}$ and 444 significantly widen the QRS-complex and block $I_{\mathrm{Na}}$ in the rat heart. The observed differences between the effect of racemates and particular isomers support the idea of development and testing of new drugs as pure isomers. Results of the in vivo and in vitro experiments agreed well in the case of 444, however, not in the case of 44Bu. It implies that in vivo experiments play an important role in the pre-clinical testing of new drugs.

\section{Účinek nově syntetizovaných látek 44Bu a 444 na šíři QRS-komplexu a na rychlý sodíkový proud: rozdíly mezi izomery}

Nově syntetizované sloučeniny $44 \mathrm{Bu}$ a 444 potlačují akonitinem vyvolanou arytmii a blokují rychlý sodíkový proud $I_{N a}$ v srdci laboratorního potkana. O jejich účinku na parametry EKG křivky však dosud nebyla publikována žádná data. V této studii jsme se zaměřili na účinek jak racemátů, tak jednotlivých izomerů látek $44 \mathrm{Bu}$ a 444 na změnu šíře QRS-komplexu v pokusech in vivo na laboratorních potkanech a na účinek těchto substancí na $I_{N a}$ v izolovaných komorových srdečních buňkách laboratorního potkana (technika whole cell patch-clamp, pokojová teplota). Všechny varianty látek $44 \mathrm{Bu}$ a $444(1,5 \mathrm{mg} / \mathrm{kg})$ způsobily signifikantní prodloužení QRS-komplexu s maximem v 1. nebo 2. minutě po jejich intravenózním podání. Racemát látky 44Bu prodloužil QRS-komplex ze 16,8 $\pm 0,4$ na $26,3 \pm 0,5$ ms (o $57 \%$ ), signifikantně více než R- (o $33 \%$ ) and S-izomer (o $36 \%$ ). Racemát látky 444 prodloužil QRS-komplex z 20,6 $\pm 1,1$ na 34,2 $\pm 1,0$ ms (o 66 \%), srovnatelně s S-izomerem (o 63 \%), nicméně více než R-izomer (rozšíření o $49 \%$ ). Co se týká vlivu na $I_{N a}$, látka 44Bu způsobila významně hlubší blokádu $I_{N a}$ ve srovnání s látkou 444 při podání ve stejné koncentraci $3 \mu \mathrm{mol} / 1(\sim 0,1 \mathrm{mg} / \mathrm{kg})$. Racemát a R-izomer látky 44Bu blokovali $I_{\mathrm{Na}}$ stejně (blokáda 91,7 $\pm 0,8 \%$ respektive $91,8 \pm 1,6 \%$ ), avšak signifikantně více než S-izomer $(82,4 \pm 2,3 \%)$. R-izomer látky 444 blokoval $I_{N a}$ méně než racemát a $\mathrm{S}$-izomer $(31,7$ $\pm 3,9 \%$ oproti $48,3 \pm 4,7$ a 50,2 $\pm 4,1 \%$ ). Lze tedy říci, že jak racemáty, tak jednotlivé izomery látek 44Bu a 444 prodlužují QRS-komplex a blokují $I_{N a}$, nicméně jejich účinky se významně liší. Míra poměrného prodloužení QRS-komplexu v in vivo pokusech neodpovídala velikosti blokády $I_{N a}$ po aplikaci 44Bu u experimentů na izolovaných buňkách, což vyzdvihuje důležitost in vivo pokusů při preklinickém testování nových léčiv.

\section{Acknowledgments}

We thank Dr. G. Christé for reading the manuscript and valuable comments and Mrs. B. Vyoralová and Mr. P. Matejovič for the technical assistance. This work has been supported by the grant projects GACR No. 305/06/0863, IGA MZd CR No. NR9126-3/2006, MSM0021622402 from the Ministry of Education, Youth and Sports of the Czech Republic, and AV0Z 20760514 from the Institute of Thermomechanics of Czech Academy of Science.

\section{Conflicts of interest}

The authors declare that they have no conflict of interest.

\section{References}

Agrawal YK, Bhatt HG, Raval HG, Oza PM, Gogo IPJ 2007: Chirality-a new era of therapeutics. Mini Rev Med Chem 7: 451-460

Akita M, Kuwahara M, Tsubone H, Sugano S 1998: ECG changes during furosemide-induced hypokalemia in the rat. J Electrocardiol 31: 45-49

Barbier GH, Shettigar UR, Appunn DO 1995: Clinical rationale for the use of an ultra-short acting beta-blocker: esmolol. Int J Clin Pharmacol Ther 33: 212-218

Bartosova L, Frydrych M, Vaculova G, Berankova K, Bebarova M, Opatrilova R, Strnadova V, Mokry P, Brunclik V, Kolevska J, Krcmar J, Bartosikova L, Florian T, Necas J 2006: Ultrashort bradycardic effect of newly synthesized compounds. Acta Vet Brno 75: 183-196 
Bartosova L, Novak F, Frydrych M, Opatrilova R, Brunclik V, Kolevska J, Mokry P, Kollar P, Bebarova M, Strnadova V, Necas J 2007: Antiarrhythmic effect of newly synthetized compound 44Bu on model of aconitineinduced arrhythmia - compared to lidocaine. Eur J Pharmacol 575: 127-133

Bartosova L, Berankova K, Souckova I, Parak T, Bebarova M, Frydrych M, Suchy P 2008: Aconitine- intoxication from the perspective of the occurrence of heart rhythm disorders and possibility of therapeutic intervention of a newly synthesized compound 44Bu. Toxicology Letters 180S: S229

Bébarová M, Matejovič P, Pásek M, Šimurdová M, Šimurda J 2005: Effect of ajmaline on action potential and ionic currents in rat ventricular myocytes. Gen Physiol Biophys 24: 311-325

Brisinda D, Caristo ME, Fenici R 2006: Contactless magnetocardiographic mapping in anesthetized Wistar rats: evidence of age-related changes of cardiac electrical activity. Am J Physiol Heart Circ Physiol 291: H368-H378

Callans DJ 2008: Apples and oranges: comparing antiarrhythmic drugs and catheter ablation for treatment of atrial fibrillation. Circulation 118: 2488-2490

Carmeliet E, Mubagwa K 1998: Antiarrhythmic drugs and cardiac ion channels: mechanisms of action. Prog Biophys Mol Biol 70: 1-72

Eap CB, Crettol S, Rougier JS, Schläpfer J, Sintra Grilo L, Déglon JJ, Besson J, Croquette-Krokar M, Carrupt PA, Abriel H 2007: Stereoselective block of hERG channel by (S)-methadone and QT interval prolongation in CYP2D6 slow metabolizers. Clin Pharmacol Ther 81: 719-728

Jamie H, Kilian G, Dyason K, Milne PJ 2002: The effect of the isomers of cyclo(Trp-Pro) on heart and ionchannel activity. J Pharm Pharmacol 54: 1659-1665

Králová E, Mokrán T, Murín J, Stankovicová T 2008: Electrocardiography in two models of isoproterenolinduced left ventricular remodeling. Physiol Res 57 Suppl 2: S83-S89

Kulig K, Malawska B, Nowicki P 2004: Influence of the absolute configuration on pharmacological activity of antihypertensive and antiarythmic drugs. Pol J Pharmacol 56: 499-508

Liu H, Tateyama M, Clancy CE, Abriel H, Kass RS 2002: Channel openings are necessary but not sufficient for use-dependent block of cardiac $\mathrm{Na}(+)$ channels by flecainide: evidence from the analysis of disease-linked mutations. J Gen Physiol 120: 39-51

Maatz LF, Wood GJ, Rivero DH, Saldiva PH 2009: Tracheal instillation of urban PM(2.5) suspension promotes acute cardiac polarization changes in rats. Braz J Med Biol Res 42: 207-213

Magyar J, Rusznák Z, Harasztosi C, Körtvély A, Pacher P, Bányász T, Pankucsi C, Kovács L, Szûcs G, Nánási PP, Kecskeméti V 2003: Differential effects of fluoxetine enantiomers in mammalian neural and cardiac tissues. Int J Mol Med 11: 535-542

Mokrý P, Csöllei J, Račanská E, Tumová I, Zemanová-Durmisová M 2001: Syntéza a studium potenciálních blokátorů beta-adrenergních receptorů s ultrakrátkým účinkem. $30^{\text {th }}$ conference Synthesis and analysis of drugs, p. 87

Mokrý P, Zemanová M, Csöllei J, Račanská E, Tumová I 2003: Synthesis and pharmacological evaluation of novel potential ultrashort-acting $\beta$-blockers. Pharmazie 58: 18-21

Opatrilova R, Mokry P, Bartosova L 2005: Characteristics and attributes of new potential drug. Chem. Zi 1, 142

Quon CY, Mai K, Patil G, Stampfli HF 1988: Species differences in the stereoselective hydrolysis of esmolol by blood esterases. Drug Metab Dispos 16: 425-428

Ranger S, Talajic M, Lemery R, Roy D, Villemaire C, Nattel S 1991: Kinetics of use-dependent ventricular conduction slowing by antiarrhythmic drugs in humans. Circulation 83: 1987-1994

Remme CA, Wilde AA, Bezzina CR 2008: Cardiac sodium channel overlap syndromes: different faces of SCN5A mutations. Trends Cardiovasc Med 18: 78-87

Roden DM, Anderson ME 2006: Proarrhythmia. Handb Exp Pharmacol 171: 73-97

Saitoh M, Sugiyama A, Nakazawa T, Hashimoto K 2002: Cardiovascular effects of orally administered HNS32 , an originally synthesized azulene-1-carboxamidine derivative, assessed in the in vivo rat model. Jpn J Pharmacol 89: 316-319

Sakai R, Inoue D, Ishibashi K, Inoue M, Shirayama T, Yamahara Y, Asayama J, Nakagawa M 1995: Kinetics of frequency-dependent conduction delay by class I antiarrhythmic drugs in human atrium. J Cardiovasc Pharmacol 25: 953-960

Shimizu W, Antzelevitch C, Suyama K, Kurita T, Taguchi A, Aihara N, Takaki H, Sunagawa K, Kamakura S 2000: Effect of sodium channel blockers on ST segment, QRS duration, and corrected QT interval in patients with Brugada syndrome. J Cardiovasc Electrophysiol 11: 1320-1329

Shinozaki T, Satoh S, Miura M, Iwabuchi K, Takeuchi M, Suzuki S, Baba S, Katoh H, Funakoshi M, Keitoku M, Watanabe J, Ishide N, Shirato K 1997: The rise time of the monophasic action potential--a new index of local use-dependent conductivity by sodium channel blockers in human myocardium. Jpn Circ J 61: 979-987

Singh S, Murawski MM 2007: Implantable cardioverter defibrillator therapy and the need for concomitant antiarrhythmic drugs. J Cardiovasc Pharmacol Ther 12: 175-180

Stoschitzky K, Koshucharova G, Lercher P, Maier R, Sakotnik A, Klein W, Liebmann PM, Lindner W 2001: Stereoselective effects of (R)- and (S)-carvedilol in humans. Chirality 13: 342-346

Šimurdová M, Nováková Z, Nováková M, Šumbera J, Christé G, Šimurda J 1997: Kinetics of propafenoneinduced block of sodium current in rat ventricular myocytes. Scripta medica 70: 263-275

Valenzuela C, Snyders DJ, Bennett PB, Tamargo J, Hondeghem LM 1995: Stereoselective block of cardiac 
sodium channels by bupivacaine in guinea pig ventricular myocytes. Circulation 92: 3014-3024

Wang RX, Jiang WP, Li XR, Lai LH 2008: Effects of (S)-amlodipine and (R)-amlodipine on L-type calcium channel current of rat ventricular myocytes and cytosolic calcium of aortic smooth muscle cells. Pharmazie 63: $470-474$

Xiao YF, Ke Q, Wang SY, Yang Y, Chen Y, Wang GK, Morgan JP, Cox B, Leaf A 2004: Electrophysiologic properties of lidocaine, cocaine, and n-3 fatty-acids block of cardiac Na+ channels. Eur J Pharmacol 485: $31-41$

Yoshida Y, Terajima K, Sato C, Akada S, Miyagi Y, Hongo T, Takeda S, Tanaka K, Sakamoto A 2008: Clinical role and efficacy of landiolol in the intensive care unit. J Anesth 22: 64-69 
